\title{
Who are the Ianfu (Comfort Women)?
}

\author{
Kirsten Orreill \\ University of Queensland
}

\begin{abstract}
The aim of this article is to understand who the Ianfu are via a social-historical and socio-cultural study. I set out to contextualise the reality of the women's lives as Ianfu and as surviving Ianfu through the inclusion of recollections of former Korean Ianfu and official histories. Who are the Ianfu, what did they do, where did they go, why were they created, and what happened to them? These are the questions that I sought to answer in order to frame the Ianfu experience through a retelling of their past. Furthermore, there are several reasons why Korean women came to comprise the majority of Ianfu which I endeavour to explain in this article.
\end{abstract}

\section{Keywords}

Comfort Women, Ianfu, Pacific War, Rape, Slavery

\section{Introduction}

'A commissioned officer took me to the next room which was partitioned off by a cloth. Even though I did not want to go he dragged me into the room. I resisted but he tore off all of my clothes and in the end he took my virginity. That night, the officer raped me twice.'

This is the testimony of Kim Hak-sun who was among as many as 200,000 women - mainly Korean but also Burmese, Chinese, Dutch, Eurasians, Indians, Indonesian, Japanese, Filipina, Taiwanese, Vietnamese, and Pacific Islanders - who were tricked, coerced, or kidnapped by the Japanese military into a life of forced 'military sexual slavery'2 during the Asia-Pacific War which is commonly known to the Japanese as

Yoshimi, Jügun Ianfu (Comfort Women), p. 141. All references made to Yoshimi, Jügun Ianfu (Comfort Women), are translated by the author. 2 This term is used by McDougall in an investigation conducted on behalf of The United Nations Commission on Human Rights, see McDougall, Contemporary Forms of Slavery. 
WWII and its preceding conflicts. ${ }^{3}$ Up to 80 percent of the women are purported to have been Korean. ${ }^{4}$ They were called the Comfort Women.

The term itself is translated from the Japanese abbreviation Ianfu, ${ }^{5}$ hereafter referred to in this paper. As the Chinese characters 慰 安 [i : an ] (comfort or solace) and 婦 [fu] (woman or wife) suggest, the women's literal purpose was to offer solace and comfort to Japan's Imperial Forces. However, the initiation of the Ianfu system was primarily a contiguous response to the Nanking massacre where it became evident to the Japanese authorities that future measures needed to be taken to minimise rapes of local women by Japanese soldiers in war zones. ${ }^{6}$ Thus, in order to minimise these rapes, the Ianfu system was used to procure women for the sexual gratification of the Japanese soldiers. ${ }^{7}$

The Ianfu symbolise diverging perspectives to all parties concerned. For Korea, surviving Ianfu victims symbolise '... not only the degradation of the Korean people but also the collective wish to reclaim national sovereignty and integrity. ${ }^{8}$ Thus, Korea is making efforts to reclaim this lost national sovereignty through popularisation of the Ianfu issue. As such, Korea has utilised surviving Ianfu as a symbolic tool to bolster Korean nationalism and to remind Japan of its obligation to the Korean nation. For example, Korea raised the Ianfu issue to oppose Japan obtaining a permanent seat on the UN Security Council.

While Korea wishes to seek a positive outcome, its raising of the Ianfu issue at opportune times (although advantageous) bolsters Japanese speculation about Korea's hidden agenda. By extension, it damages the validity of former Ianfu testimonies, seriously injuring the women's honour. Effectively this has distracted Japan from recognising the seriousness of this issue. This in turn affects the status of former Ianfu making it difficult for them to gain any real form of closure.

For Japan, Ianfu victims symbolise a difficult war past which previously they sought to forget. As a general policy, Japan is still trying to mitigate its actions to the world for the use of thousands of women as military sexual slaves during the war by the Japanese Imperial Forces. This point becomes more apparent when contrasted against the fact that the Japanese government is yet to prosecute and convict any Japanese war

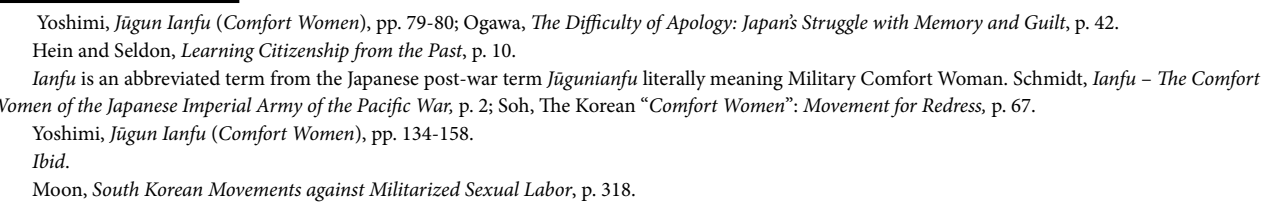


criminal or person in relation to military sexual slavery. ${ }^{9}$ The Japanese government's lack of action to raise consciousness of the seriousness of these crimes is reflective of Japan's current political stance on the Ianfu issue. Previously, this lack of consciousness has led Japan to exclude all mention of Ianfu in junior high-school history textbooks and to make claims that Ianfu were paid prostitute camp followers for which they received international condemnation. ${ }^{10}$

For former Ianfu, they remember their reality as it was: a life of sexual torture and a lifetime of persecution to follow. ${ }^{11}$ Today, they want a sincere apology from the Japanese government which may or may not include compensation. ${ }^{12}$ They want to tell their story to the public before they die, they want the Japanese government to be made accountable for their actions, and they want their story to be written into the history textbooks so that it will never be forgotten and never repeated again.

\section{Aims}

The primary aim of this article is to understand who the Ianfu are via a socio-historical and socio-cultural narrative study. I also aim to contextualise the reality of the women's lives as Ianfu and as surviving Ianfu through the inclusion of recollections of former Korean Ianfu and official histories. Furthermore, there are several clear reasons why Korean women came to comprise the majority of Ianfu which I intend to explain in this article. My interest lies in personalising the reality of the Ianfu and this is coupled with my desire to offer an extensive depiction of their lives under the Ianfu system.

\section{The Beginning of their Lives as Ianfu}

[Japanese] officials believed [international] laws were not applicable to Japan's colonies, and this, combined with the belief in the superiority of Japanese women and the suitability of women of other races for prostitution, cemented the decision to use women from colonies and occupied territories as [Ianfu]. ${ }^{13}$

\footnotetext{
Hayashi, Survey of the Japanese Movement Against Wartime Sexual Violence, p. 9.

Ienaga, Japan's past, Japan's future: one historian's odyssey.

Soh, Human Rights and the "Comfort Women"; Tanaka, Japan's Comfort Women.

Schellstede, Comfort Women Speak: Testimony by Sex Slaves of the Japanese Military.

Tanaka, Hidden Horrors: Japanese War Crimes in World War II, p. 97.
} 


\section{The Beginning}

Officially, recruitment of Ianfu is believed to have originated with the beginning of the second Sino-Japanese War in $1937 .{ }^{14}$ However, it has been suggested that Ianfu may have been pressed into service as early as 1932 when the first comfort station, hereafter ianjo, ${ }^{15}$ was established in Shanghai. ${ }^{16}$ It was in this year when Lieutenant-General Okamura Yasuji - the Deputy Chief of Staff of the Shanghai Expeditionary Army and the original proponent of ianjo for the Japanese Army - in response to the Shanghai Incident proposed the establishment of brothels in Japanese occupied areas to prevent further rapes of Chinese civilians. ${ }^{17}$ However, although ianjo existed in Shanghai prior to 1937, it appears it was not until the later half of that year that the military implemented systematic expansion of ianjo as a contiguous response to the Nanking Massacre. ${ }^{18}$ The authorities then in earnest set about sourcing Ianf $u$ to make available for the purpose of sexual recreation. ${ }^{19}$

As discussed briefly in the introduction, Ianfu recruits were mobilised from many locales (occupied by the Japanese military) in Asia. ${ }^{20}$ The precise number of women taken from these areas is unknown, due to many relevant official documents being destroyed or hidden by the Japanese military at the conclusion of the war. ${ }^{21}$ Approximations based on available documents put the number of women in the system at somewhere between 80,000 and 200,000, among which most scholars agree up to 80 percent were Korean. ${ }^{22}$ However, the private memoirs of Lieutenant-General Okamura Yasuji make it apparent his initial intentions were to use professional Japanese prostitutes for Ianfu recruits, rather than non-Japanese women. ${ }^{23}$

\section{The Selection of Women}

Initially, recruitment of non-Japanese women was partly because the military leaders realised that the required numbers of Ianfu would outstrip the number of professional Japanese prostitutes available to take up the position. ${ }^{24}$ Additionally, many Japanese

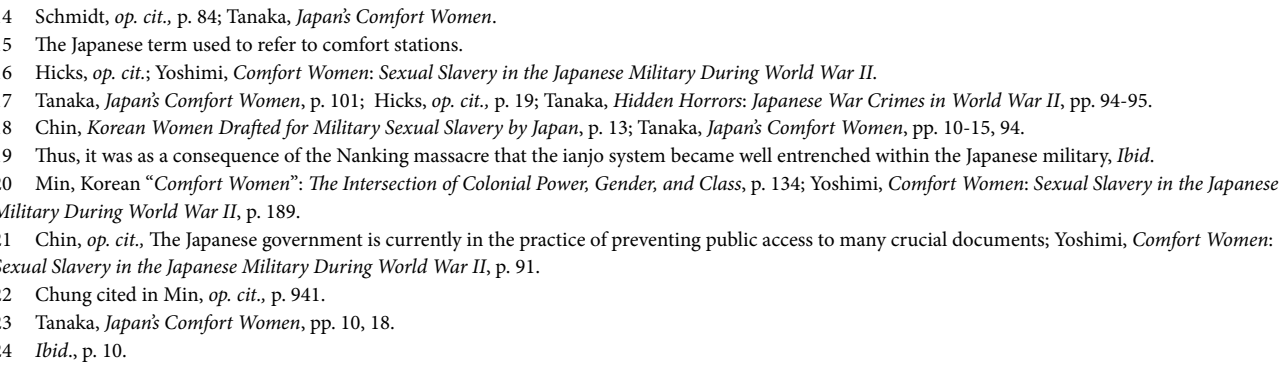


.

prostitutes were older and often infected with venereal disease; as such, they would not do as gifts from the Emperor to his Imperial Forces. ${ }^{25}$ Thus, it became clear the exploitation of Japanese women on such a large scale was neither acceptable nor possible. Ianfu recruits had to be found elsewhere.

The resulting solution was to source women from Japan's colonies and Japanese occupied territories concentrating particularly on Korean women. This came about as a direct result of Japanese occupation of their lands. ${ }^{26}$ After the Russo-Japanese War from 1904-1905, Korea had become a protectorate of Japan although it was not formally colonised until 1910 when it was given the name Chōsen by the Japanese. ${ }^{27}$ Thus, by the commencement of the war Korea was already a colony of Japan.

This coupled with the Japanese Diet's move in 1938 to pass the National General Mobilization Act - empowering the government to bypass Diet approval in appropriation of resources and labour - meant the government of Japan could now place all resources of the Japanese Imperial Empire - including Korean colonial subjects - at the disposal of the war effort. ${ }^{28}$ This allowed Japan's entry and colonisation into Korea to play a significant role in the exploitation of a large portion of Korean women as Ianfu. ${ }^{29}$

Furthermore, the idea of colonialism suggests that conquest was made by a more powerful and a materially and psychologically advanced empire than that of the colonised. As such, the plight of Korean women can be linked to the failure of their country to avoid colonisation by Japan and by extension the same principle would apply to other Japanese occupied territories. ${ }^{30}$ Furthermore, Korea's cultural and spatial proximity to Japan made its women more susceptible than women from other Japanese colonies, this was also fundamental to their selection. Evidently, it would seem women who were selected as Ianfu were the by-product of historical circumstance brought about by Japanese occupation of their lands.

In spite of the fact that Korea was now a colony of Japan, Japanese sentiment dictated that - even though Korean nationals under colonial rule were assimilated in the Japanese way - they were still considered racially inferior. ${ }^{31}$ So much so, that Korean activists and researchers alike assert that Japanese national prejudice against Koreans was

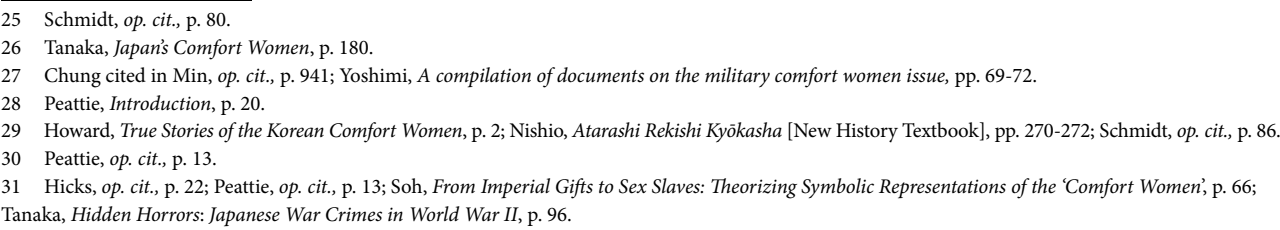


one of the major sources contributing to the victimisation of Korean women. ${ }^{32}$

The belief that soldiers could avoid contracting sexual diseases or at least minimise their chances and thus stay healthy for the war was a further contributing factor in the choice to use Korean women. ${ }^{33}$ Japanese journalist Senda Kako ${ }^{34}$ posits the report submitted in 1939 by Dr. Asō Tetsuo - a gynaecologist and a probationary medical officer at the Army Communication Hospital in Shanghai at the time - was partly responsible for the idea to use predominantly Korean women for this purpose. ${ }^{35}$ This report was based on initial findings the previous year regarding the incidence of venereal disease among women he examined who were soon to become Ianfu at a location in Shanghai. ${ }^{36}$ In his findings he states:

Among those from the Peninsula [hanto - the Japanese term used to refer to Korea as part of Japan] there was very little indication indeed of venereal disease, but those from the Homeland [Japan proper] although free of acute symptoms at present, were all extremely dubious. In age, these were all past 20, some approaching 40, and had already spent a number of years in prostitution. Those from the Peninsula presented a pleasing contrast, being the main younger and unsophisticated. ${ }^{37}$

He goes on in his report saying: 'Prostitutes are no good for the sacred Imperial Army' implying only the sacred sacrifice of a virgin would make an appropriate 'gift' when it came to an Imperial soldier's comfort. ${ }^{38}$

As mentioned previously, Japanese women who were used as Ianfu were most likely already professional prostitutes before entering ianjo, which meant many were already carriers of various sexually transmitted diseases. ${ }^{39}$ Many of them were also too old for a life of prostitution and as a result unable to continue earning a living in Japan. ${ }^{40}$ On the other hand, their younger Korean counterparts on the whole had no sexual experience prior to their employment in ianjo and were considerably healthier and therefore more desirable. Their virginity was a result of strong patriarchal customs in Korea before and during the war which called for absolute obeisance to maintaining virginity for unmarried women. ${ }^{41}$

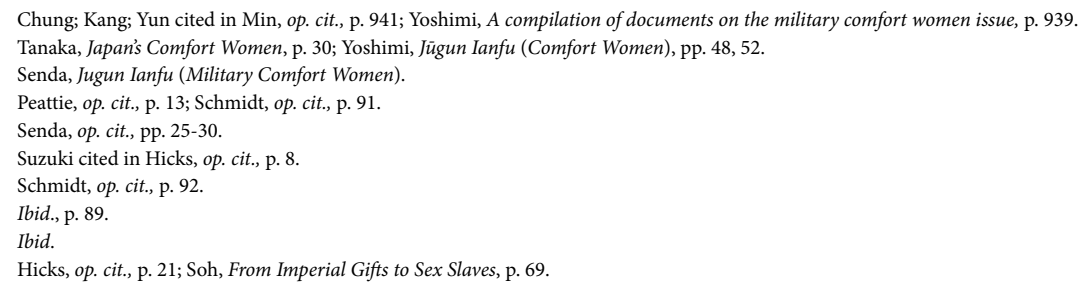


Thus, while exploiting Asian women, the Japanese wartime government did not exploit their own women to the same extent. Non-Japanese women were chosen because of the Japanese belief in their own superiority over and above any other Asian race. In particular, Korean women were chosen because of the strong Japanese belief that they were most suited to a life of prostitution. ${ }^{42}$ As many were virgins they served the military's purpose for establishing ianjo, making them ideal Ianfu candidates for Japan. Furthermore, Yoshimi ${ }^{43}$ suggests that the Japanese military chose not to use Japanese virgins as Ianfu because of the potential public distrust of the military.

Evidently, historical circumstance, geographical location, and ethnic discrimination contributed equally to the popular choice to use Korean women as Ianfu recruits. Thus, the Japanese forces' move to concentrate on selecting Ianfu recruits from Korea was as much due to the absence of effective power to resist it as it was to specific policies and planning implemented under Japanese colonisation. For these reasons it would appear Japan's choice of women was equally deliberate as situational in origin.

\section{Purpose of Recruitment}

The purpose for procurement of Ianfu can be traced back to four factors. First, they were procured to assist in the prevention of wide-spread rape of local women in Japanese occupied areas. ${ }^{44}$ It was believed that a steady supply of sex on offer from the military's own women would remedy this. ${ }^{45}$ However, this system was not introduced out of concern for the safety of local women in the towns and villages that the Japanese soldiers conquered. ${ }^{46}$ Rather, it was introduced as Defence Agency Director of the Secretariat Naoaki Murata claimed in a meeting held in 1992: '... to maintain order [and] to ease the anti-Japanese feeling aroused by the Japanese soldier's deeds.' ${ }^{47}$ Thus, the necessity to avoid antagonising the local populace in Japanese occupied areas prompted the authorities to make provision for their own women for the purpose of sexual relations with Japanese soldiers. ${ }^{48}$

Second, the women were procured for Japanese soldiers with the purpose of providing them with a form of leisure. ${ }^{49}$ The structure of the Japanese military meant

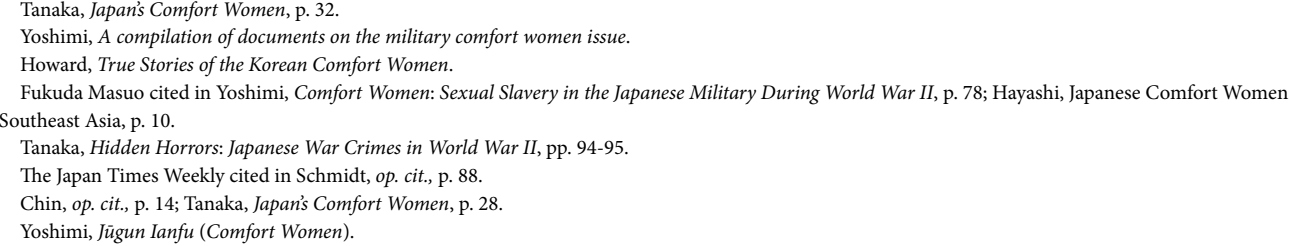


Japanese soldiers, unlike their Western counterparts, were given little if any time at all for recreational leave which was fundamental in causing poor military morale at the time. ${ }^{50}$ The authorities saw in the provision of ianjo a potential solution to boost morale and solve the recreational leave problem they faced. ${ }^{51}$ The following passage in a War Ministry circular expresses the Japanese rationale:

In particular the [sexual] psychological influence received from [ianjo] is most direct and profound and it must be realised how greatly their appropriate direction and supervision affect the raising of morale, the maintenance of discipline and the prevention of crime and venereal disease. ${ }^{52}$

Members of the Japanese military were then allowed to visit these facilities during their recreation time. In fact as Suzuki Yoshio points out - a former sergeant major in the Japanese military - ianjo '... were effectively the only place the soldiers had to go when given leave. ${ }^{53}$

It was also thought that sex would adequately relieve soldiers from the stress of combat and give them an outlet from strict military discipline. ${ }^{54}$ A soldier who visited an ianjo in China reflects frankly on his visit there highlighting the importance of the women to the soldiers:

Even though we had just returned from lengthy military operations at the front the thought of having sex made us leave immediately for the ianjo. When we arrived at where the women were, soldiers took their place in line and mulled over life and death while waiting their turn. There was nothing else like the supreme feeling of completeness that the soldiers experienced when engaging in sex with the women. This was the only way for them to whole-heartedly escape from their abnormal existence. ${ }^{55}$

Effectively, the women provided solace and an escape from the war, if only temporary. Thus, instead of seeing to it that their men were provided leave to go home the authorities implemented alternative facilities where the men could take their recreation leave. ${ }^{56}$

Third, the need to contain the rapid increase of venereal disease among Japanese soldiers had become paramount. ${ }^{57}$ In his testimony, Suzuki Yoshio asserted that soldiers

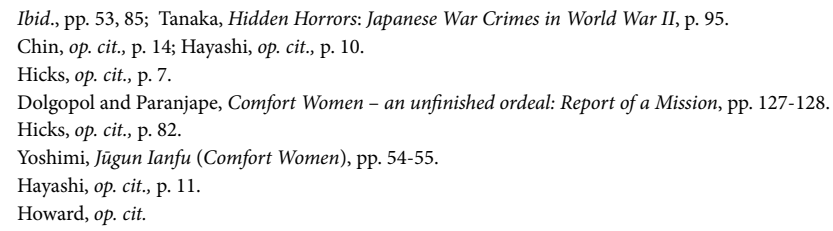


who had been in the military for four to five years had a disease rate of 30 to 40 percent and indicated that this was the source of the spread of venereal disease among the women. ${ }^{58}$ Apparent to the authorities was that they would be able to restrict the sexual activities of soldiers to a controlled environment to a greater degree in a military style brothel. ${ }^{59}$ From this, we can see that the Japanese military saw in the women the solution to decrease incidences of infection.

Fourth, the women were also procured with the idea in mind to prevent espionage within the Japanese military. ${ }^{60}$ Ichikawa Ichiro - a member of the military police (commonly known as kempeitai) ${ }^{61}$ assigned to a regiment in Manchuria highlights how real this concern was for the military authorities, saying that it was common practice for ianjo managers to provide a list of users corresponding to each woman every morning to military police. ${ }^{62}$ The kempeitai would then check for any irregularities such as a soldier making too many visits to a particular Ianfu or to ianjo in comparison to his salary. ${ }^{63}$

The fact that kempeitai kept regular tabs on ianjo highlights how real security concerns and the threat of espionage were for Japanese authorities. ${ }^{64}$ By providing ianjo facilities for their men, where the women were specially selected and tightly controlled, the authorities believed they could restrict the sexual activities of Japanese soldiers within this environment thus minimising the risk of security breaches. ${ }^{65}$

It was with these four factors in mind that the selection of Ianfu was carried out, thus introducing the Ianfu system to the Pacific War. The Ianfu system was a Japanese strategy to keep Japanese men fighting for longer periods of time and boost their morale through the provision of a military controlled form of sex. The four points listed for the initial establishment of ianjo and selection of Ianfu demonstrate control of the soldier as well as the women.

\section{Ianjo Locations and the Dispersal and Diffusion of Ianfu}

Ianjo locations paralleled the movements of Japanese forces, following them into even

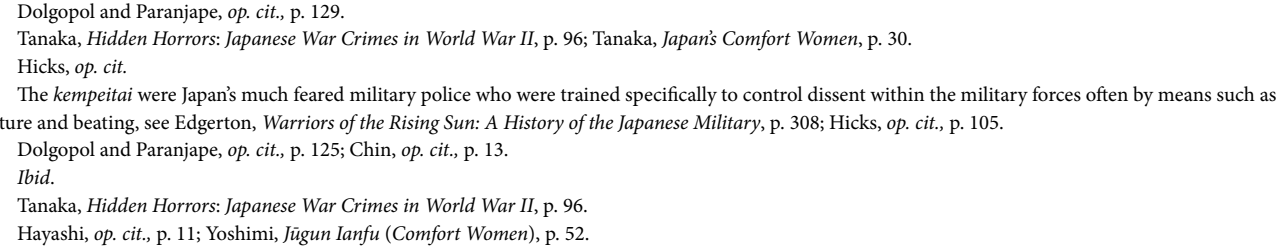


the remotest areas of Asia occurring with the expansion of the war after the attack on Pearl Harbour in December $1941 .^{66}$ This was when ianjo became ubiquitous in the AsiaPacific region bringing with them the omnipresence of Ianfu. ${ }^{67}$ Japanese, American, and Dutch official documents have confirmed the existence of ianjo in China, Hong Kong, French Indochina, the Philippines, Malaysia, Singapore, British Borneo, the Dutch East Indies, Burma, Thailand, New Guinea, the Japanese Okinawan archipelago, ${ }^{68}$ the Bonin Islands, Hokkaidō, and Sakhalin. ${ }^{69}$ Yoshimi $^{70}$ states it is impossible to know the total number of ianjo, however even conservative estimates put the number at more than a thousand. For these reasons, during the Pacific War it is fair to assume Ianfu were to be found wherever the Japanese flag flew - including Japanese war zones, Japanese occupied territories, Japanese colonies, and Japan proper.$^{71}$

\section{A Day in the Life of an Ianfu}

In poor health the women contracted tuberculosis and venereal disease for which they did not receive sufficient treatment. Crippled in body and broken in spirit they awaited their death. ${ }^{72}$

\section{Arriving at Ianjo}

Many ianjo were converted from abandoned homes, barns, churches, or requisitioned hotels. ${ }^{73}$ Dr. Asō depicts the exterior façade of an ianjo location somewhere between Shanghai and Nanking describing it as thus:

The stations consisted of ten barrack block-like huts, together with a supervisor's hut, all enclosed by a fence. The huts were divided into ten small rooms, each numbered and with a separate door. ${ }^{74}$

This basic design was to become the prototype for the construction of many subsequent ianjo. $^{75}$

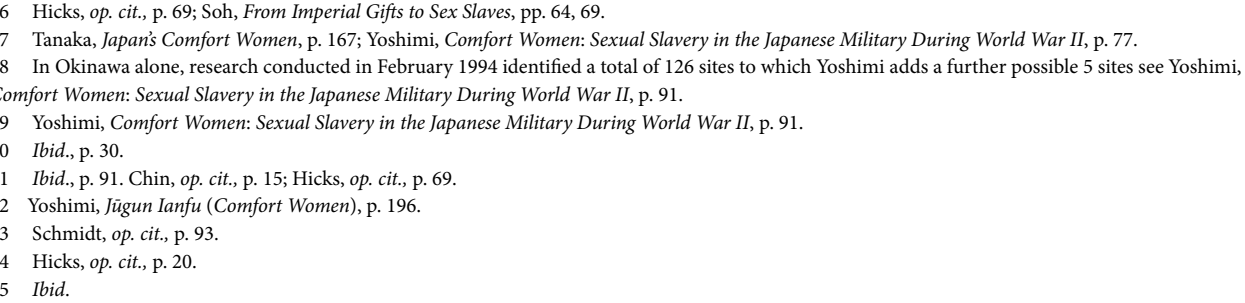


The interior of ianjo were mainly simple in design. Tanaka ${ }^{76}$ describes each room being divided by thin plywood walls. In some locations where there were no such walls, curtains were used instead to screen off rooms. Each of these rooms consisted of a bed or futon. In bathrooms and toilets a disinfectant solution (made of potassium permanganate solution or cresol soap solution) was made available. ${ }^{77}$ Yun Soon-man when asked to describe the conditions at the ianjo she was located in depicts a scene common to most saying:

... there were long lines of soldiers and that each soldier was given a very short period of time to be in the room with an individual woman. If any soldier took "too long" there would be banging on the door and other soldiers would be calling for them to come out. ${ }^{78}$

In some ianjo locations, women describe conditions where they were forced to sit in chairs lined up in the hallway where Yi Yong-suk ${ }^{79}$ remembers:

There was a placard on the wall behind each of the chairs which bore our name and number. We remained seated as the soldiers came in to choose whoever took their fancy to take to bed.

At other ianjo locations, descriptions are given of soldiers spontaneously ejaculating or publicly masturbating while waiting in the queue in order not to suffer premature ejaculation when it came to their turn. ${ }^{80}$ Even from the perspective of Japanese soldiers, the ianjo was a bizarre place where one officer stationed in Nha Trang, Vietnam remarks:

Previously I had heard gossip about the place where the " $p i$ 's1 were but when I think about it, it really did not even begin to describe this bizarre world. In broad daylight men boldly stood in line, their coats undone and their pants unfastened waiting one by one to have sex right in front of me. The men advanced anxiously rather than eagerly turned out one by one like a convenience system. I flinched at the sight of this surreal world. ${ }^{82}$

On arriving at ianjo some women were assigned Japanese names while others were given a number as in the case of Kim Yoon-shim ${ }^{83}$ who was known as number

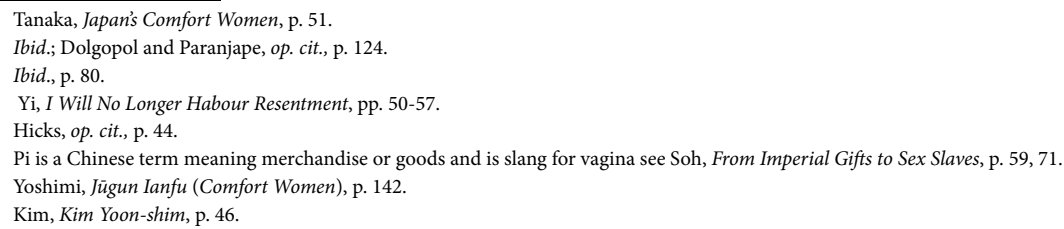


27. There are testimonies of some women being tattooed with an identifying mark on their arm for easy recognition if they escaped. ${ }^{84}$ When it came to conversing in their own language Kim Young-shil ${ }^{85}$ said she was told by a Japanese soldier on her arrival if she were to speak in Korean she would be killed. When one girl spoke in Korean she describes an officer severing the girl's neck to teach the women a lesson. ${ }^{86}$

On arrival it was common practice for a non-commissioned officer to conduct a registration process checking the women's official documents including personal photographs, family registers, personal declaration forms, guardian consent forms, police permits, and town council identification papers. ${ }^{87} \mathrm{~A}$ copy of the documents was then passed on to the relevant authorities. ${ }^{88}$

Here, many women were put through an initiation process as $\mathrm{Hicks}^{89}$ portrays in the case of Kim Chun-ja:

Once she was naked, her captor gave her a thorough inspection and pronounced her fit to provide ample comfort to the men of his unit. He then proceeded to break her in with an initiation lasting four hours. He forced her into endless variations as she wept with grief, pain and shame. The same sort of treatment was repeated over the following three days, the girls being rotated among the men.

In order to make the women succumb to their sexual demands, the soldiers beat many women into submission. ${ }^{90}$ Many former Ianfu testimonies indicate new girls were kept for the express use of officers. ${ }^{91}$ In some locations women were instructed in tricks of the trade. For example, first and foremost they were taught in order to maintain their stamina they should not over-exert themselves or become excited while working. ${ }^{92} \mathrm{Next}$, it was also forbidden that they form an attachment with a soldier although this rule was frequently broken. ${ }^{93}$ The women were then given instructions on what particular style of service they should offer differing clientele which Hicks ${ }^{94}$ describes:

They were to take a leisurely approach to older men, to praise the sexual technique of officers, and to bring some suggestion of a less mercenary, more

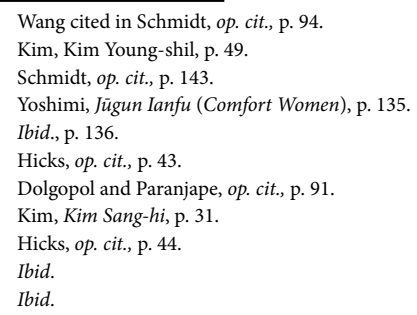


.

romantic approach to young and unsophisticated soldiers.

In some locations, it also seems the women were taught limited Japanese phrases such as; irashaimase (welcome) which they were to use to greet the soldiers. ${ }^{95}$

The Result - Escape, the Use of Narcotics, and Suicide

As a result of conditions at ianjo, many women contemplated escape. Most ianjo were heavily patrolled by the Japanese military and the women's activities were severely restricted in order to prevent escape. ${ }^{96}$ Furthermore, because many women were taken to serve in foreign lands where they did not know the local language, customs, or area and often had no money once they escaped from ianjo, many felt they had nowhere to run and no one to turn to for help. ${ }^{97}$ Ha Sun-nyo recounts her attempt at escape:

\begin{abstract}
About one year had passed since I came to Shanghai when I stole away in the snow from the ianjo. When the rickshaw arrived at its last stop the night had already fallen. I had nowhere to run and I didn't know the language, I hardly slept. I kept dozing in and out of sleep worrying someone would find me and force me to return to the ianjo. Before I knew it, it was dawn. The more I thought about it the more I realised that I had nowhere to run. So I decided to return. I crept back into the kitchen. I cooked some rice and sat down at the table when my manager screamed at me to stop eating. However, I did not stop. I continued eating while the manager beat me violently calling me an escapee. ${ }^{98}$
\end{abstract}

In some cases the punishment for escape was more severe than in the case depicted above. Kang Soon-ae describes what happened when one woman failed an escape attempt: 'One of the women stabbed an officer but he did not die. They built a mound to bury her up to her neck. They gathered all us and made us watch as she was beheaded'. ${ }^{99}$

Often the difficulties a woman experienced in navigating her way around a foreign land while trying to blend into the crowd proved more difficult than her initial escape. To add to this, local kempeitai and authorities were on the lookout for escapees. ${ }^{100}$ Escape from ianjo was no easy task and the difficulties the women faced on escaping coupled with the

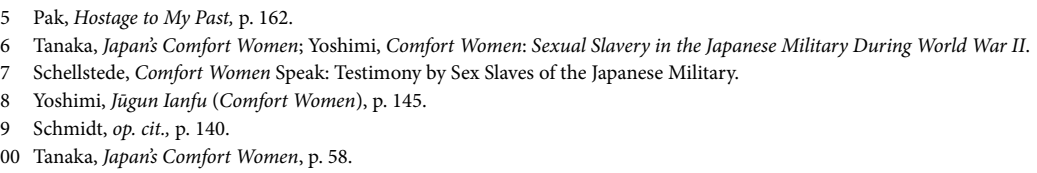


threat of repercussions if they failed were great. No doubt this made many women reconsider an escape attempt.

With physical escape difficult, many women turned to the use of narcotics, usually opium or philopon as a form of psychological escape. ${ }^{101}$ It has also been suggested that some ianjo managers used narcotics as an incentive, allowing their women to buy them if they worked hard. ${ }^{102}$ In ianjo locations where it was difficult to obtain narcotics, medics have been documented supplying drug-addicted women with substitute morphine injections. ${ }^{103}$ However, many women turned to suicide often by drinking the cresol soap provided to them as a disinfectant while others drank a concoction of drugs and alcohol. ${ }^{104}$

Alternatively, some women were killed when depressed soldiers chose a favourite Ianfu to commit double suicide with them. ${ }^{105}$ Often this occurred in the face of Japan's inevitable defeat where it was the popular Japanese custom to follow the habitual tradition of gyokusai - from the Chinese literally meaning broken jewel. ${ }^{106}$ Hicks ${ }^{107}$ describes how in one such incident, surviving Ianfu were forced by military authorities to participate in this tradition:

[In Lameng the] commanding officer considered evacuating the women while the chance remained [but] he was persuaded by his adjutant [that the women] would prefer to die with the men. However, since it was doubtful that the women would follow in the gyokusai tradition he had his sergeant throw down two hand grenades into their dugout late at night while they slept.

As a result of their physical treatment at ianjo, some women lost their minds, many women were left crippled in body and others were killed.

\section{Life after the War}

The women managed to survive an extremely harsh life on the battlefields of a foreign war, but the reality they have been forced to face since their return to

\footnotetext{
101 Ibid., p. 59.

102 Ibid.

103 Kawada Fumiko cited in Tanaka, Japan's Comfort Women, p. 59.

104 Ibid.

105 Ibid., Chin, op. cit., p. 23; Yoshimi, Jügun Ianfu (Comfort Women), p. 158.

106 A term for the Japanese tradition where in the face of defeat one would either fight to the death or as an alternative, commit mass suicide. As Hicks states the saying goes: 'it is better to be a jewel and be broken than a tile and remain whole: [meaning] an honourable death is better than a dishonourable life' Hicks, op. cit., p. 113.

107 Ibid., p. 114
} 
Korea in peacetime has been nothing short of a continuation of their hardship, even though in a different form. ${ }^{108}$

\section{Repatriation of Ianfu after the War}

At the end of the war, a considerable number of women were repatriated to their homelands, especially those located in ianjo throughout China and from the more stable areas in Southeast Asia. ${ }^{109}$ On the other hand, it appears that women from unstable areas often were left to settle where the Japanese forces left them. ${ }^{110}$ However, Chin ${ }^{111}$ purports that the majority of women were not repatriated.

There are cases where in the absence of an official repatriation policy, soldiers took pity on the women and saw to their return personally, usually smuggling them onboard their own repatriation ships. ${ }^{112}$ In some cases, it seems that the repatriation of women was carried out begrudgingly. For example, a nurse protested to soldiers about cramped conditions that Ianfu endured in the hold of the ship headed to Japan from Surabaya to which she received the reply: 'There is no need to treat them as human. They're less than cattle. They should be thankful we've taken them at all.'113

However, according to a 1994 U.N. press release, only 30 percent of the initial 80 percent of Korean women are recorded to have survived the war which is a survival rate of less than one in three. ${ }^{114}$ This was partly because of methods employed by some units to kill the women at the time of Japan's defeat, in order to hide evidence of their existence. ${ }^{115}$ Former Ianfu testimonies support this. ${ }^{116}$ The opinion that the women would be an embarrassment to Japan if left alive and that they would be an encumbrance to evacuate with the retreating Japanese troops often led to the conclusion to dispose of them. ${ }^{117}$

Sometimes, methods employed by Japanese soldiers to remove the women extended to torture as Kang ${ }^{118}$ indicates saying: '... one woman had her breast cut off and another had her stomach cut open by a Japanese soldier'. This was in response to

\footnotetext{
108 Chin, op. cit., p. 24

109 Hicks, op. cit., pp. 122-123.

110 Ibid., p. 122.

111 Chin, op. cit., p. 23

112 Hicks, op. cit., p. 123; Yoshimi, Comfort Women: Sexual Slavery in the Japanese Military During World War II, p. 92.

113 Hicks, op. cit., p. 123

114 Soh, Human Rights and the "Comfort Women", pp. 123-124.

115 Chin, op. cit., p. 23; Soh, From Imperial Gifts to Sex Slaves, p. 66.

116 Ibid:; Tanaka, Japan's Comfort Women, p. 59.

117 Kim II Myon 1976 cited in Hicks, op. cit., p. 115; Soh, From Imperial Gifts to Sex Slaves, p. 66.

118 Dolgopol and Paranjape, op. cit., pp. 89-90.
} 
finding out that Japan had lost the war. In her own case, a Japanese soldier attacked her with intent to kill her, stabbing her in the back and striking her on the back of the head with the sword. ${ }^{119}$

However, the practice of abandoning the women was far more common than deliberate elimination. ${ }^{120}$ During the time of Japan's surrender to the Allied Powers, many women woke up to find their Japanese captors had vanished. As Hwang Kum-joo explains for example:

One day, when we woke up, we discovered that there were no soldiers' queues and there was nobody in sight. There was no sign of any food ... All the Japanese soldiers had run away. There were just the eight of us girls left behind. ${ }^{121}$

In the face of Japan's defeat, it was Ichikawa Ichiro's belief '... that many of the [Korean] women were lost because the soldiers did not know what to do about them.' ${ }^{122}$ He added that even in the end, Korean women in particular were discriminated against when it came to repatriating women back to their homeland, saying that many Japanese soldiers who left on trains would not allow Koreans to board. ${ }^{123}$

\section{Home-Coming for Ianfu - Economic Hardship and Abandonment}

For many women, the end of the war and their repatriation to their homelands did not bring relief. Many women and in particular Korean women were ostracised by their friends, relatives, and their local communities because they harboured suspicions about the nature of their employment during their absence. ${ }^{124}$ Many of them, in order to survive, tried their hand at anything as Kim Bun-sun ${ }^{125}$ explains: '... I made a living by peddling almost everything I could lay my hands on, such as tobacco, vegetables, and rice-crackers.' Some women are suspected to have turned to prostitution. ${ }^{126}$

It is fair to say that wartime experiences affected many women's chances of having a stable family life, greatly affecting their future happiness. ${ }^{127}$ Most of these women are bitterly resentful of this. ${ }^{128}$ Kang Duk-kyung ${ }^{129}$ relays her sorrow:

\footnotetext{
119 Ibid.

120 Chin, op. cit., p. 23; Hicks, op. cit., pp. 72, 117.

121 Dolgopol and Paranjape, op. cit., p. 97.

122 Ibid., pp. 126-127.

123 Ibid.

124 Chin, op. cit., p. 24; Hicks, op. cit.

125 Kim, Kim Bun-sun, p. 23.

126 Tanaka, Japan's Comfort Women; Schmidt, op. cit.

127 Ibid., p. 125

128 Chin, op. cit., p. 24

129 Kang, Kang Duk-kyung, p. 19.
} 
.

Over the years, I had several marriage proposals. But I did not have enough strength to overcome my low self-esteem, guilt, and past nightmares to get married and raise a family. Completely affected by my past, I could not be happy in my marriage. Korea was liberated, and all the Japanese left from our land, but I couldn't be happy. All these years I have lived in secret, in shame, and in pain.

Also, many former Ianfu were left barren as a result of their time in ianjo which meant that they could not bear heirs - a serious problem in a patriarchal society. ${ }^{130}$ According to published testimonies, these women are deeply saddened by the fact that they could not have children and feel now in their old age that they have no one. ${ }^{131}$

\section{The Women's Suffering under Korean Patriarchal Culture}

Many women believed the revelation of their past would bring shame on their family and at a great emotional strain to themselves went to any lengths to keep their past hidden. Patriarchal cultural practices, contemporary to Korea at the time, lie at the heart of their reasoning to choose silence as their course of action. ${ }^{132}$ In their reasoning, the women identify with the Korean ideal held at the time that a respectable woman was a virtuous woman. From birth, this idea remained a cultural imprint on the women and is prevalent throughout their testimonies. ${ }^{133}$ Howard ${ }^{134}$ describes what happened when surviving Ianfu came home:

When they returned to Korea, they came back as hwanghyang nyo. ${ }^{135}$ To the Koreans around them, they were neither faithful nor chaste. They were not exemplary women. The families of Ianfu feared the ostracism they would suffer if the shameful past was discovered; the women became an extra burden, and there was little chance to marry them off.

Even today, because of social pressures spawned out of patriarchal culture, many women who have come forward and given testimony use pseudonyms. ${ }^{136} \mathrm{It}$ is fair to assume too, that many women have yet to come forward because of this pressure. ${ }^{137}$

\footnotetext{
130 Chin, op. cit., pp. 15, 24; Hicks, op. cit., p. 125.

131 Schellstede, op. cit.

132 Chin, op. cit., p. 11; Hicks, op. cit., p. 125; Schellstede, op. cit.

133 Ibid.

134 Howard, True Stories of the Korean Comfort Women, p. 7.

135 The Korean term meaning home-coming woman.

136 Howard, op. cit., p. vii.

137 Chin, op. cit., p. 24.
} 


\section{Lingering Physical and Mental Trauma}

Apart from social ostracism, many women are still affected by resulting physical symptoms from venereal disease and physical abuse. One woman told interviewers of how debilitating injuries that she had sustained working as an Ianfu in China and Sumatra had affected her health decades later, saying: 'my abdomen used to hurt terribly, as if my womb was being cut away from me. ${ }^{138}$ Additionally, many women had also developed mental disorders and had nervous breakdowns. ${ }^{139}$

As surviving Ianfu, they suffered lingering physical ailments and extended psychosomatic trauma as a result of these experiences. They became victims of patriarchal culture where they were socially ostracised. Many of the women experienced great difficulty establishing normality to their lives and did not achieve financial stability in their lives, leaving them with little support both financially and emotionally. Chin purports ${ }^{140}$ there are even women who want to avoid all contact with other human beings. That the women still suffer so profoundly is testament to the level of abuse they were subject to as Ianfu and how deeply it has affected them.

\section{Conclusion}

Occasionally people come to hear my story of a former [Ianfu]. I am reluctant to talk about it because it is my shameful, terrible past. Recollecting such a past is so emotionally draining. ${ }^{141}$

This article has examined the question: 'Who are the Ianfu?' incorporating the use of a socio-historical and socio-cultural study. It has set out to contextualise the lives of Ianfu past and present including official and personal histories. It also sought to explain the reasons behind the inclusion of Korean women and to account for their high percentage as Ianfu.

This narrative shows that Ianfu were women who were taken by the Japanese military into a life of military sexual slavery during the Pacific War. These women were mainly young and most were virgins (particularly Korean women) who were pressed into service as a result of Japanese occupation of their lands.

With specific reference to Korean women, it was Korea's spatial and cultural

\footnotetext{
138 Yi, Wandering around Manchuria,China and Sumatra, p. 141.

139 Choe, Silent Suffering, p. 176.

140 Chin, op. cit., p. 24

141 Yi, Yi Young-sook, p. 101.
} 
.

proximity to Japan, coupled with Japanese discriminatory practices against Koreans which contributed to their high numbers in the Ianfu system. They were given by the Emperor of Japan as 'gifts' to his men with the soldier's comfort, solace, recreation, health, and morale in mind.

Thus, while the Ianfu system provided a solution to the Japanese authorities it also transferred the value of women into a basic commodity for everyday usage. The system constituted sexual, racial, ethnic, economic, and class based discrimination. ${ }^{142}$ As Ianfu, they were racially, sexually, and socially persecuted. They lived an existence whereby they endured physical abuse and repeated sexual torture and as a result often suffered from psychological and physical illnesses throughout their lives.

\section{The Japanese Response}

Contemporary Japan is deeply divided over its post-war responsibility when it comes to the matter of the Ianfu. Those on the right believe that the Ianfu system was a necessary evil. According to 1998 and 1999 opinion surveys over two-thirds of Japanese military veterans: '... replied that Japan should neither apologize nor compensate [Ianfu] survivors because they were paid for their services' says Soh. ${ }^{143}$ In June 1996, when the then Ministry of Education (now called the Ministry of Education, Culture, Sports, Science, and Technology) announced its approval of the inclusion of Ianfu in middle school history textbooks, sectors of the Japanese public reacted negatively, requesting the removal of them. ${ }^{144}$ Descriptions given in the textbooks were brief, listing the women in the order of: 'Women were made to accompany the military ... and were treated horribly', making no reference specifically to Ianfu or the nature of their conditions. ${ }^{145}$

Furthermore, in some instances Ianfu have been intermittently referred to as kosho (licensed prostitutes) by Japanese conservatives, including former veteran politicians and cabinet ministers. ${ }^{146}$ For instance, in June 1996 Okuno Seisuke, a former cabinet member and Justice Minister, asserted that the women pursued prostitution of their own volition, merely as a commercial activity and all claims suggesting that the women had been coerced were unfounded. ${ }^{147}$ The leader of the Liberalist groups - Liberalist History Research Group and Japanese Society for History Textbook Reform

142 Min, op. cit., p. 939; Soh, Human Rights and the "Comfort Women", pp. 123-124.

143 Soh, Japan's National/Asian Women's Fund for the "Comfort Women", p. 232.

144 Kitazawa, Textbook history repeats itself, p. 53; Sand, Historians and Public Memory in Japan, p. 3; Yoshimi, Comfort Women: Sexual Slavery in the Japanese Military During World War II, p. 25.

145 Ibid.

146 Soh, From Imperial Gifts to Sex Slaves, p. 60.

147 Minister Okuno has also publicly admitted to his personal involvement in incinerating official documents in advance of the American occupation forces arrival. Sand, op. cit., p. 2; Yoshimi, Comfort Women: Sexual Slavery in the Japanese Military During World War II, p. 12. 
or Council for the Creation of New History Textbooks established in 1995 and 1996 respectively - Fujioka Nobukatsu, along with his co-founder Nishio Kanji assert that the women were nothing more than professional prostitutes, making a very good living during the war when compared to Japanese soldiers. ${ }^{148}$ Kobayashi Yoshinori, a manga (Japanese comic book) artist and also a member of the History Textbook Reform group produced manga in 1997 and again in 1998 which depicted Ianfu as prostitutes. ${ }^{149}$ Both were best sellers. Yoshimi ${ }^{150}$ notes that their influence can not be underestimated in a society where the young largely no longer read books or newspapers and in which the media of manga is immensely popular.

However, there is a growing Japanese awareness of the necessity to come to terms openly and honestly with its war responsibility. ${ }^{151}$ The question 'What do you think about politicians' and the government's response to the [Ianfu] issue?' was put to the Japanese public in a telephone survey conducted by a Japanese television network, JNN in February 1997.152 50.7 percent of respondents replied saying: ' $\{$ Politicians have\} made many thoughtless remarks and should apologize properly to Asian countries and the victims.' ${ }^{153}$ These remarks given by members of the Japanese government and Japanese public reaction can provide some insight then, on where Japan currently stands on the Ianfu issue in a political and public sense.

\section{A Growing International Awareness and Support}

Legally and publicly, the Ianfu debate has come as far as it has today largely as a result of increasingly vocal women's groups campaigning to turn the issue into a greater one over women's rights. ${ }^{154}$ Their push for feminist scholarly research into the Ianfu issue and general intensification of it helped change societal attitudes in Korea, preparing the way for former Ianfu to make public their stories. ${ }^{155}$ As a result of their efforts, they brought to the attention of the Korean public and the world the gravity of the Ianfu issue for the first time. ${ }^{156}$

Furthermore, rulings made by international governing bodies such as the United Nations Commission on Human Rights (UNCHR) and the Geneva based International

\footnotetext{
148 McCormack, Japan's uncomfortable past, p. 6; Sand, op. cit., p. 2; Soh, From Imperial Gifts to Sex Slaves, p. 73

149 Yoshimi, Comfort Women: Sexual Slavery in the Japanese Military During World War II, p. 26.

150 Ibid.

151 Soh, Japan's National/Asian Women's Fund for the "Comfort Women", p. 216.

152 Yoshimi, Comfort Women: Sexual Slavery in the Japanese Military During World War II, p. 27.

153 Ibid.

154 Hicks, op. cit., pp. 133; Soh, From Imperial Gifts to Sex Slaves, p. 124.

155 Howard, op. cit., pp. 3-4.

156 Hicks, op. cit., pp. 133; Soh, Human Rights and the "Comfort Women", p. 124.
} 
incus is

Commission of Jurists (ICJ) ${ }^{157}$ have also contributed to the debate in recent years. In investigations conducted on behalf of UNCHR in 1998, the Ianfu system was categorised as 'military sexual slavery' and ianjo were described as 'rape centres.' 158 It was concluded therefore that the Ianfu system constituted military sexual slavery which must be prosecuted as a crime against humanity and in the later report it was also stipulated that the Japanese government must prosecute those responsible and compensate its victims. ${ }^{159}$ These rulings have significantly changed public perception and attitudes to women's rights, empowering the women to address their past. ${ }^{160}$ What is more, as Soh ${ }^{161}$ points out, these hearings categorically shifted the nature of the Ianfu debate:

... from bilateral disputes over Japan's insufficiently acknowledged post-war responsibility toward Korean victims ... to an international indictment of Japan's violations of women's human rights during the War.

Recent years have also seen an international shift to address the dehumanising effects of rape, resulting in a redefinition of rape as a human rights problem, aiding the Ianfu debate considerably. ${ }^{162}$ With this, the representation of Ianfu categorically changed to 'military sex slaves.' ${ }^{163}$ Also, as the international community's understanding of rape in armed conflict moved into a human rights problem, the Ianfu debate developed organically, replicating this in its grounds for legal redress. The actions taken by Korean women's groups and the international community at large meant that the women were now given an opportunity to channel their energies into attempting to receive recognition and recompense.

Furthermore, the women's age, the change in social climate, the fact that many of them had no living relatives or were ostracised by them, and the realisation that this was probably going to be their last chance to make public their story, compounded in them a feeling that they had nothing to lose, making it the right time for them to come forward. ${ }^{164}$ All these factors provided the right environment and the grounds for the Ianfu story to emerge, enabling Ianfu plaintiffs to sue the Japanese government for compensation.

In regards to compensation from the Japanese government, over and above

\footnotetext{
157 In 1994 the ICJ compiled a report on the Ianfu issue in which their findings established, among others, the then Japanese government was directly responsible for the running of the Ianfu system and for the women's suffering under it (Dolgopol and Paranjape, op. cit., pp. 201-202).

158 McDougall, Contemporary Forms of Slavery.

159 Ibid.

160 Howard, op. cit., p. 7 .

161 Soh, From Imperial Gifts to Sex Slaves, p. 60.

162 Mackinnon cited in Soh, From Imperial Gifts to Sex Slaves, p. 72.

163 Ibid.

164 Howard, op. cit., p. 7.
} 
anything else, to receive a clear apology from the Japanese government appears to be the main form of compensation the women want. ${ }^{165}$ However, there are also many women in favour of receiving monetary compensation. ${ }^{166}$

While Japan has issued several public apologies (made by Japanese prime ministers to former Ianfu in the 1990s), these apologies were of a private nature rather than of an official nature. Similarly, Japanese government financial contributions have been made to private funds set up to compensate surviving Ianfu. ${ }^{167}$ However, as of yet, Japan has not compensated any former Ianfu through official channels. Kim Soon$\operatorname{duk}^{168}$ relays her thoughts on this:

I am very unhappy with the Japanese government today. It was good they finally admitted their past crime. But their apologies are only half-hearted. They try to let civilian organizations pay some compensation. But it was the government's deeds.

Continuing on, Kim Soon-duk ${ }^{169}$ explains her annoyance of her own government saying:

I am unhappy with the Korean government also. They asked us to come out from hiding and to speak out to let people know the truth. So I did. I spoke out my past that had been hidden even from my mother. Now I wish the Korean Government would be more forceful in representing our interests, and help us regain our dignity. I wish they would pursue it vigorously until our goals are achieved.

Many women feel the same way and see Korea's actions as being motivated by wishing not to antagonise the Japanese government to the point where Japanese-Korean financial aid may be jeopardised. ${ }^{170}$ Thus, Korea will not advance the Ianfu issue if it is at the expense of the provision of Japanese funds that improve the Korean economy. ${ }^{171}$

When it comes to just one wish for all of the women I believe Kim II Myon ${ }^{172}$ expresses it best saying: "From what he knew of many, they would prefer to "rub out the past with an eraser, if that were possible." ${ }^{173}$ If only this were possible, I am sure all women would choose this as their preferred form of compensation.

\footnotetext{
165 Howard, op. cit.; Schellstede, op. cit.

166 Ibid.

167 Soh, Japan's National/Asian Women's Fund for the "Comfort Women", p. 221.

168 Kim, Kim Soon-duk, p. 40

169 Ibid.

170 Howard, op. cit.; Schellstede, op. cit.; Soh, Politics of the Victim/Victor Complex, p. 158; Yoshimi, Comfort Women: Sexual Slavery in the Japanese Military

During World War II, pp. 5-6.

171 Ibid.

172 Kim II Myon in Hicks, The Comfort Women, p. 127.

173 This was in response to Yoshida Seiji's recommendation that a memorial be erected in the women's honour at Yasukuni Shrine (Ibid.).
} 
New Voices Volume 2

\section{References}

Choe, M.-s., 'Silent Suffering', in Howard, K. (ed.), True Stories of the Korean Comfort Women (London: Cassell, 1995), pp. 167-176.

Chin, S. C., 'Korean Women Drafted for Military Sexual Slavery by Japan', in Howard, K. (ed.), True Stories of the Korean Comfort Women, (London: Cassell, 1995), pp. 11-30.

Dolgopol, U. and Paranjape, S., 'Comfort Women - an unfinished ordeal: Report of a Mission', International Commission of Jurists Geneva, 1994.

Edgerton, R. B., Warriors of the Rising Sun: A History of the Japanese Military (New York: W.W. Norton \& Company, Inc., 1997).

Hein, L. and Selden, M., 'Learning Citizenship from the Past: Textbook Nationalism, Global Context, and Social Change', Bulletin of Concerned Asian Scholars, vol. 30, no. 2 (1998), pp. 3-15.

Hicks, G. L., The Comfort Women (St Leonards: Allen \& Unwin Pty Ltd, 1995).

Hayashi, H., 'Japanese Comfort Women in Southeast Asia', Japan Forum, vol. 10, no. 2 (1998), pp. 1-12.

Howard, K. (ed.), True Stories of the Korean Comfort Women (London: Cassell, 1995).

Kang, Duk-kyung., 'Kang Duk-kyung', in Schellstede, S. C. (ed.), Comfort Women Speak: Testimony by Sex Slaves of the Japanese Military (New York: Holmes \& Meier Publishers, Inc., 2000), pp. 15-19.

Kim, Bun-sun., 'Kim Bun-sun', in Schellstede, S. C. (ed.), Comfort Women Speak: Testimony by Sex Slaves of the Japanese Military (New York: Holmes \& Meier Publishers, Inc., 2000), pp. 21-23.

Kim, Soon-duk., 'Kim Soon-duk', in Schellstede, S. C. (ed.), Comfort Women Speak: Testimony by Sex Slaves of the Japanese Military (New York: Holmes \& Meier Publishers, Inc., 2000), pp. 37-41.

Kim, Sang-hi., 'Kim Sang-hi', in Schellstede, S. C. (ed.), Comfort Women Speak: Testimony by Sex Slaves of the Japanese Military (New York: Holmes \& Meier Publishers, Inc., 2000), pp. 29-31.

Kim, Yoon-shim., 'Kim Yoon-shim', in Schellstede, S. C. (ed.), Comfort Women Speak: Testimony by Sex Slaves of the Japanese Military (New York: Holmes \& Meier Publishers, Inc., 2000), pp. 43-47.

Kim, Young-shil., 'Kim Young-shil', in Schellstede, S. C. (ed.), Comfort Women Speak: Testimony by Sex Slaves of the Japanese Military (New York: Holmes \& Meier Publishers, Inc., 2000), pp. 49-51.

Kitazawa, T., 'Textbook history repeats itself', Japan Quarterly, vol. 48, no. 3 (2001), pp. 51-53.

McCormack, G., 'Japan’s uncomfortable past', History Today, vol. 48, no. 5 (1998), pp. 5-6.

McDougall, G. J., 'Contemporary Forms of Slavery: Systematic rape, sexual slavery and slavery-like practices during armed conflict', The United Nations Commission on Human Rights, 1998.

Min, P. G., 'Korean “Comfort Women”: The Intersection of Colonial Power, Gender, and Class', Gender and Society, vol. 17, no. 6 (2003), pp. 938-957. 
Moon, K. H. S., 'South Korean Movements against Militarized Sexual Labor', Asian Survey. vol. 39, no. 2 (1999), pp. 310-327.

Nishio, K., Atarashi Rekishi Kyōkasho (New History Textbook) (Fusō: Fusō, 2001).

Ogawa, S., 'The Difficulty of Apology: Japan's Struggle with Memory and Guilt', Harvard International Review, vol. 22, no. 3 (2000), pp. $42-46$.

Pak, S., 'Hostage to My Past', in Howard, K. (ed.), True Stories of the Korean Comfort Women (London: Cassell, 1995), pp. 158-167.

Peattie, M. R., 'Introduction' in Peattie, M. R. and Myers, R. H. (eds.), The Japanese Colonial Empire 1895-1945, (Princeton: Princeton University Press, 1984), pp. 1-52.

Sand, J., 'Historians and Public Memory in Japan: The "Comfort Women" Controversy', History and Memory, vol. 11, no. 2 (1999), pp. 115-126.

Schellstede, S. C. (ed.), Comfort Women Speak: Testimony by Sex Slaves of the Japanese Military (New York: Holmes \& Meier Publishers, Inc., 2000).

Schmidt, D. A., Ianfu - The Comfort Women of the Japanese Imperial Army of the Pacific War (Lewiston: The Edwin Mellen Press, 2000).

Senda, K., Jugun Ianfu (Military Comfort Women) (Tokyo: Sanichi Shobo, 1978).

Shimazu, N., 'Popular Representations of the Past: The Case of Postwar Japan', Journal of Contemporary History, vol. 38, no. 1 (2003), pp. 101-116.

Shuko, O., 'The difficulty of apology', Harvard International Review, vol. 22, no. 3(2000), p. 42.

Soh, C. S., 'The Korean “Comfort Women”: Movement for Redress', Asian Survey, vol. 36, no. 12 (1996), pp.1226-1240.

—, 'From Imperial Gifts to Sex Slaves: Theorizing Symbolic Representations of the "Comfort Women"', Social Science Japan Journal, vol. 3, no. 1 (2000a), pp. 59-76.

—, 'Human Rights and the “Comfort Women”', Peace Review, vol. 12, no. 1 (2000b), pp. 123-129.

—, 'Japan's National/Asian Women's Fund for “Comfort Women”', Pacific Affairs, vol. 76, no. 2 (2003a), pp. 209-233.

—, 'Politics of the Victim/Victor Complex: Interpreting South Korea's National Furor over Japanese History Textbooks', American Asian Review, vol. 21, no. 4 (2003b), pp. 145-178.

—, 'Women's Sexual Labor and State in Korean History', Journal of Women's History, vol. 15, no. 4 (2004), pp. 170-177.

Tanaka, Y., Hidden Horrors: Japanese War Crimes in World War II (Boulder: Westview Press, 1996).

-, Japan's Comfort Women: Sexual slavery and prostitution during World War II and the US occupation (London: Routledge, 2002).

Ueno, C., 'The Politics of Memory: Nation, Individual and Self', History and Memory, vol. 11, no. 2 (1999), p. 129-145. 
.n.m.n.m \&

Yi, T., 'Wandering around Manchuria, China and Sumatra', in Howard, K. (ed.), True Stories of the Korean Comfort Women (London: Cassell, 1995), pp. 134-142.

Yi, Young-sook., 'Yi Young-sook', in Schellstede, S. C. (ed.), Comfort Women Speak: Testimony by Sex Slaves of the Japanese Military (New York: Holmes \& Meier Publishers, Inc., 2000), pp. 99-101.

Yi, Yong-suk., 'I Will No Longer Harbour Resentment', In Howard, K. (ed.), True Stories of the Korean Comfort Women, (London: Cassell, 1995), pp. 50-57.

Yoshimi, Y., A compilation of documents on the military comfort women issue (Seoul: Sumundang, 1993).

—, Jügun Ianfu (Comfort Women) (Iwanami: Yasue Ryousuke, 1995)

-, Comfort Women: Sexual Slavery in the Japanese Military During World War II (New York: Columbia University Press, 2000). 